\title{
Coverage of Issues Related to Sexual Violence: Comparative Study of The Indian Express and The Times of India
}

\author{
Afaq Ahmad \\ Assistant Professor, Department of Journalism and Mass Communication, \\ Lovely Professional University, Punjab, India \\ E-Mail: afaqmasscom@gmail.com
}

\begin{abstract}
Newspapers are considered the important platforms to mobilise and sensitise the people regarding different social issues. The issues of the women, their rights and atrocities meted out against them, need to be raised in various forums including the newspapers. This study is aimed at understanding news media's agenda on issues related to women with specific reference to sexual violence meted out against them. To analyse the coverage of the issues relating to sexual violence against women, two mainstream national English dailies. The Indian Express and The Times of India were purposively chosen. The systematic random sampling technique was employed to select the contents published in the newspapers between 01 January to 30 June 2017. It was revealed that the newspapers had given more prominence to negative aspects of women's issues and presented their image as a consumable product. There has been a little variance in tonality and resonance of reporting between the two newspapers under study. The findings also reveal that there are numerous incidents of sexual harassment against women to which the newspapers paid scant attention and it seems that they are not in the news agenda. Most of the times, the news stories pertaining to women's rights were presented in negative frames.

Keywords: Women's Rights, Content Analysis, Framing, The Times of India, The Indian Express, Sexual Violence
\end{abstract}

\section{INTRODUCTION}

Gender-based violence languishes in the patriarchal character and prototypical masculinity of the society. These thoughts and notions are based on the dominance over women and that vehemently recognizes the power and robustness of men. These complexities of the society willingly construed into hazardous sexual behaviours, exploitative sexual practices and other acts of violence against women. According to the Convention on the Elimination of all Forms of Discrimination Against Women (CEDAW), 'discrimination against women' shall mean "... any distinction, exclusion, or restriction made on the basis of sex which has the effect or purpose of impairing or nullifying the recognition, enjoyment or exercise by women, irrespective of their marital status, on a basis of equality of men and women, of human rights and fundamental freedoms to the political, economic, social, cultural, civil or any other field”.

"Women in Asia and the Middle East are eliminated in the name of honour. Girls in West Africa tolerate genital mutilation in the name of custom. Migrant and refugee women in Western Europe are castigated for not adopting the social customs and traditions of their host community. Young girls in Southern Africa are forcefully raped and infected with HIV/AIDS because the perpetrators think that sexual intercourse with virgins will provide the antidote for their sickness. And in the richest, most developed countries of the world, women are battered to death by their partners" (Amnesty International, 2004, p. iii-iv). As for domestic violence, it seems to be not a topic of discourse in the media. How media channels communicate stereotypes and reactions about the issue can certainly impact how the issue is addressed and treated.

The portrayal of rape, attempt to rape and rape-cum-murder and the fate of victims in the criminal justice system need to be highlighted and exposed by the newspapers. The depiction of victims in the newspapers can give information on how victims are treated in letter and spirit and how reactions about sexual violence, domestic violence, rape, honour killing, and other women's rights violations are constructed. For example, the term "prostitute" symbolizes a woman as a criminal, whether she was forced into prostitution or not. This research will attempt to analyse the consequential impact on victims after a piece of news covered related to sexual violence by the newspapers under study. One of the possible consequences that will be addressed is whether their victimization is only promoted by the newspapers, such as, if the perpetrator of the crime is arrested for committing rape and imprisoned or the social status of a rape victim is upheld.

In Indian society, gender stereotypes seem to have an impact on how violence against women is addressed by print media. The mass media ought to play a positive role in these circumstances and should enlighten the facts as to how a woman is battered and also how a woman reacts to being battered. The expectations of the readers generated and reflected in the press lend themselves to shaping attitudes of victimization and how violence against women is promulgated and ultimately addressed in the society and the criminal justice system. It is a well-established notion that domestic violence thought to occur behind closed doors and should be handled as such. The issue is not perceived to be as widespread, and many believe that these victims are not the sufferer of sexual violence, but statistics prove otherwise. Hundreds of thousands of women are sexually 
abused in the country on certain intervals and almost every person knows that the victim affected by domestic abuse and/or sexual assault is close relative to her.

"Rape and sexual assault against women are the most underreported crimes due to certain stigmas. The blamegame against a victim is rampant, even in the court of justice, when talking about rape victims. How the victim dressed, where she was when she was raped, what time it was when she was raped, and even the victims' sexual history is used to justify the act and blame the victim for her circumstances. Seventy-five percent of victims know their perpetrator and as a result may be even more reluctant to report the crime or pursue charges, due to devastating social implications. With one in six women being victimized sexually, this problem, like domestic violence, is widespread and perturbs and devastates virtually everyone"(RAINN.org, 2009). "Sexual violence has many serious repercussions for victims as well. Apart from experiencing Post Traumatic Stress Disorder, which is arduously treated, victims also undergo immense physical and psychological disorders. These include eating disorders, sleep disorders, substance abuse, self-mutilation, depression, suicide, pregnancy, STDs, and Stockholm Syndrome and so on" (RAINN.org, 2009). Now, it has become quite evident that the attitudes and implications of rape and sexual violence distress the victim, as well as the victim's family and friends, that draws catastrophic ramifications.

Likewise, sex trafficking is also a growing problem. As long as sex trafficking remains a lucrative business due to globalization and excessive mobility, the problem will remain to exist and there seems to be a never-ending supply of vulnerable victims across the corners of the world. On the contrary, the way in which victims of sex trafficking are intervened upon has a direct impact on the overall sex trafficking industry. In many cases when a police raid on a brothel suspected of employing trafficked women, the victims are detained for prostitution or unlawful immigration and either confined or expatriated. If the victims are deported back to their home countries, they leave their slavery debt unsettled. Many traffickers used subjugation debt as a way of controlling their victims. Ifa victim leaves without fulfilling her debt, the trafficker's group will more than likely trace her or her family down and demand remittance. When the family does not able to pay the debt, the victim will either be forced back into prostitution or her family members (sisters, cousins, etc.) will have to pay her debt. Therefore, intervention may be proved as a catalyst to exacerbating the consequences victims tolerate. Thus, it is imperative to understand how the media and the general public view the victimhood of trafficked women so as to not augment the molestations precipitated. The criminal justice system, as well as international law, must be delicately applied to the victims. Unless these aspects are clearly identified and understood, proper intervention and services cannot be supplied (Martin, 2013).
Mass media influence our perceptions, apprehensions, and behaviours related to gender as well as violence through many channels including newspapers, radio, television, movies, magazines, and the Internet. Hence, press and media tend to become a central concern for researchers who seek to understand the determinants of gender-based violence against women in technologically developed societies.

\section{REVIEW OF LITERATURE}

Noh et al., (2010) used newspaper reporting's of homicides committed by women to determine how these media outlets give an account of such incidences and whether the women perpetrators were seen as mad, bad, or reasonable human beings. "The researchers mention the feminist jurisprudence model for explaining women who kill their abusers, which argues that Battered Woman Syndrome (BWS) portrays the woman as someone helpless of reason or rationality. For use in their study, the argument is made that BWS defence is not a justification due to the fact that many women turn to homicide as a rationally chosen option. Gender role expectations and media portrayal insist that domestic violence is a personal problem that a woman has to solve on her own. They argue that certain stereotypes of battered women, some of which are disseminated by the media, can affect how they are treated by the criminal justice system and by other social service agencies. Such treatment is a result of the expectations that are held about the behaviour of battered women. They also argue that secondary claimsmakers, such as newspapers, have more influence over what details of the situation are accepted as truth than primary claims-makers (the battered woman)."

According to Berns (2004), "the media has a massive influence over perceptions of social problems, including domestic abuse. However, it is not just the journalist who selects what stories are covered and which are under covered or uncovered. She makes an evaluation that entertainment and ratings are prized over integrity in media journalism; outlining four key guidelines for reporting social problems in the media, focusing on magazine content. He discovered these four guidelines for reporting domestic violence after interviewing several editors of women's magazines. The first key feature is to be service-oriented; that is, the editors observed it was their mission to provide services and tools to their readers. The second guideline is to provide empowerment to readers. They do this by use of the third guideline, keeping it personal. These editors tried to keep their stories to one individual victim's story instead of providing commentary on more complex social issues. This is important for the last guideline, which is to provide an uplifting or hopeful ending. She argues that these are the key ways in which women's magazines frame abusive situations as empowering and "inspirational." With the emphasis in modern media going astray and concentrating on entertainment, stories about prolonged and ongoing turmoil and abuse are "depressing." She argues that the inspirational magazine articles are more attractive and 
marketable, even if they only report on anecdotal cases that have uplifting and positive endings. In order to reframe domestic abuse to be more "pro-male", she identified five commonalities she found in her study of men's magazines. She examined articles based on domestic violence in maledominated magazines Playboy, Penthouse, National Review, The New Republic, and Reason. She found that the content contained in the articles of these magazines is quite disturbing. First, these articles intended to reframe the problem to take the issue of gender out of the equation entirely. The author found that the contents available in the magazines under study stated that domestic violence is a "human issue," not a gendered issue. They do this by emphasizing female incidences of abuse to make it seem as if men and women abuse at the same rates. Such articles may include several personal stories about incidences where females perpetrated violence, but male perpetrated abuse is left entirely out of the discussion.”

Another example using print media sources was conducted by Heeron and Messing (2009). “They used newspaper sources found in the Lexus-Nexus database to analyse domestic homicide reports. They chose to focus primarily on reports involving multiple casualties, as they seemed to have analysed the problem as mass murder. Their sample generated 78 reports, of which 71 were committed by male perpetrators. For the purpose of their research, they focused on the 71 cases that involved male killers. The analysis revealed the heavy use of police sources, which can be problematic. This is partially true in cases where there are no living witnesses or unusual circumstances. In these cases, police accounts are taken as a testament with no other sources being unearthed. In one report of a murder that occurred almost immediately after the perpetrator was released from jail, police sources diverted the belief that this case was a failure and beyond social controls. Another piece of information revealed by the research is that some of the reports tended to support one side of the case or the other, either the prosecution or the defence. Very few reports appeared “neutral.” Reporters especially inclined to dishonour the prosecution when the victim was a foreigner, as was the case of a Philippine mail-order bride who was murdered by her husband after she alleged sexual harassment committed by her husband. However, many cases did reprimand or castigate the defence and support the victims, especially in cases where one or more of the victims were children.”

In 2009, Khondaker and Barlow also used print media to establish how such violence is constructed in the Indian subcontinent, specifically in Bangladesh. "The scholars took interest in this region because of the use of Purdah by women, an alleged conservative form of patriarchy that supposedly triggers most domestic violence. The most embarrassing and confusing matters in the region seem to be police corruption, as survey data reveals that only $2 \%$ of women who seek help for their abuse go to authorities. The researchers chose a daily English-language newspaper published in Bangladesh to conduct their study. The researchers analysed news reports of domestic violence, paying attention to how the victims and perpetrators were treated. They came to the conclusion that many murders and even some rapes were committed due to begging dowry, or the murders were connected with getting some financial goals. Even though the use of dowries is prohibited by law throughout the Indian subcontinent, the practice is still used behind closed doors. If a bride's family is unable or unwilling to pay dowry demands, a husband may murder his wife, remarry, and seek additional dowries.”

\section{OBJECTIVES OF THE STUDY}

The broader objective of the study is to understand the agenda of The Indian Express and The Times of India on women's rights. Further, the researcher formulated the following specific objectives for closer introspection:

1. To measure the coverage of different issues related to women's rights in The Indian Express and The Times of India.

2. To analyse the chosen contents disintegrated in the selected newspapers.

3. To examine and interpret the selected genre-wise stories covered by the selected newspapers.

4. To assess the role of the selected newspapers regarding upholding women's rights.

\section{RESEARCH QUESTIONS}

The research questions that will be posed are: How are the issues of sexual violence, sexual assault, child marriage, dowry death, honour killing, sex trafficking, women' reproductive rights portrayed in The Indian Express and The Times of India? How are perpetrators portrayed, and how are victims characterized? Do dominant themes include blame or shame to the victim?

Further, based on the literature review, the paper will generally inquire about the following issues

1. How women's issues are depicted in mainstream English dailies?

2. How victims of sexual violence are depicted by the newspapers under study?

3. How are the perpetrators of crime portrayed (negatively, positively) and does he suffer?

4. Do the newspapers show how the victim overcomes after being abused?

\section{RESEARCH DESIGN AND METHODS}

The present study is aimed at analysing the women's rights related news by employing the content analysis method. As content analysis is intrinsically an orderly and coherent mechanism and it is the most reliable way to enumerate and analyse the content of the print media, hence it is fetched. The present study aims to quantify and itemize the issues related to human rights with just, fair, and reasonable attention, hence, systematic random sampling was preferred 
and applied instead of simple random sampling, stratified sampling, and cluster sampling. Further, systematic random sampling was employed to reduce sampling error.

To examine the hypothesized link between the newspaper and its readers empirically, the researchers gathered timebound data through systematic random sampling. The data extracted through systematic random sampling spans from 01 January to 30 June 2017. News stories on human rights were selected in a way that was being published in every fourth day covering a period of six months. By which the researchers drew samples viz. 1, 5, 9, 13, 17, 21, 25, 29 issues of a newspaper in a month.

A. Unit of Analysis: Each and every published newspaper content that is being, directly and indirectly, relevant to women's rights issues as identified below.
B. Prominence: The space allocated to a news story on a particular page either in the Front or inside or back page determines its importance.

C. Frequency: The number of stories relevant to human rights covered by the newspaper.

D. Newspaper Items: Newspaper content that is being classified as News Stories. Further, women's rights issues have been classified as below:

Child marriage, forced marriage, Dowry death, Honour killing, Sex trafficking, Rape/attempt to rape, Sexual harassment/assault/intimidation against women, Women's reproductive rights.

\section{RESULTS AND DISCUSSION}

A. Coverage of Issues Related to Sexual Violence by The Indian Express and The Times of India

TABLE I WOMEN's RightS IsSUES AND THEIR COVERAGE

\begin{tabular}{|c|c|c|c|c|c|c|}
\hline \multirow[b]{2}{*}{ Women's Rights Issues } & \multicolumn{3}{|c|}{ The Indian Express } & \multicolumn{3}{|c|}{ The Times of India } \\
\hline & $\begin{array}{c}\text { Front } \\
\text { Page } \\
\text { Frequency } \\
\text { (Space in } \\
\left.\mathrm{cm}^{2}\right) \\
\end{array}$ & $\begin{array}{c}\text { Inside Page } \\
\text { Frequency } \\
(\text { Space in } \\
\left.\mathrm{cm}^{2}\right)\end{array}$ & $\begin{array}{c}\text { Front \& } \\
\text { Inside Page } \\
\text { Frequency } \\
\text { (Space in } \\
\left.\mathrm{cm}^{2}\right)\end{array}$ & $\begin{array}{c}\text { Front Page } \\
\text { Frequency } \\
(\text { Space in } \\
\left.\text { cm }^{2}\right)\end{array}$ & $\begin{array}{c}\text { Inside Page } \\
\text { Frequency } \\
\text { (Space in } \\
\left.\text { cm }^{2}\right)\end{array}$ & $\begin{array}{c}\text { Front \& } \\
\text { Inside Page } \\
\text { Frequency } \\
(\text { Space in } \\
\left.\mathrm{cm}^{2}\right)\end{array}$ \\
\hline $\begin{array}{l}\text { Child marriage, forced } \\
\text { marriage }\end{array}$ & $1(112.5)$ & $3(764)$ & $4(876.5)$ & $1(128.65)$ & 00 & $1(128.65)$ \\
\hline Dowry death & 00 & $1(84.5)$ & $1(84.5)$ & 00 & $1(98)$ & $1(98)$ \\
\hline Honour killing & 00 & 1 (112) & $1(112)$ & $1(16)$ & $2(408.25)$ & $3(424.25)$ \\
\hline Sex trafficking & 00 & $3(702.5)$ & $3(702.5)$ & $1(25.65)$ & 00 & $1(25.65)$ \\
\hline Rape/attempt to rape & $1(42)$ & $11(1804.5)$ & $12(1846.5)$ & $6(468.2)$ & 13 (1127.25) & $19(1595.45)$ \\
\hline $\begin{array}{l}\text { Sexual harassment/assault/ } \\
\text { intimidation/ domestic } \\
\text { violence against women }\end{array}$ & 00 & $10(1158.3)$ & $10(1158.3)$ & $6(618.5)$ & $11(1549.2)$ & $17(2167.7)$ \\
\hline $\begin{array}{l}\text { Women's reproductive } \\
\text { rights }\end{array}$ & 1 (189) & $2(268)$ & $3(457)$ & $3(130.5)$ & $11(2206.05)$ & $14(2336.55)$ \\
\hline Total coverage & $3(343.5)$ & $31(4893.8)$ & 34 (5237.3) & $18(1387.5)$ & 38 (5388.75) & $56(6776.25)$ \\
\hline
\end{tabular}

Table I discloses that The Indian Express and The Times of India simultaneously covered highest number of stories (12 with a space of $1846.5 \mathrm{~cm}^{2}$ ) and (19 with a space of 1595.45 $\mathrm{cm}^{2}$ ) respectively on rape/attempt to rape; but as far as space coverage was concerned, women's reproductive rights and sexual harassment/assault/intimidation/domestic violence against women found prominence in spite of covering a smaller number of stories compared to rape/attempt to rape in The Indian Express.

Further, on sexual harassment/assault/intimidation/domestic violence against women, The Indian Express covered 10 $\left(1158.3 \mathrm{~cm}^{2}\right)$ stories on its inside pages and not a single story got appeared on the front page of the newspaper; whereas, The Times of India given priorities to 17 (2167.7 $\mathrm{cm}^{2}$ ) stories in this category, in which 6 stories with the space of $618.5 \mathrm{~cm}^{2}$ appeared on the front page and 11 stories with $1549.2 \mathrm{~cm}^{2}$ covered on its inside pages.
News related to child marriage, forced marriage occupied the third slot in order of importance in The Indian Express. A total of 4 stories with a space of $876.5 \mathrm{~cm}^{2}$, of which a single story with $112.5 \mathrm{~cm}^{2}$ appeared on the front page and 3 stories with a space of $764 \mathrm{~cm}^{2}$ appeared on inside pages. Whereas, news stories related to women's reproductive rights acquired the third slot in The Times of India 14 $\left(2336.55 \mathrm{~cm}^{2}\right)$; of which $3\left(130.5 \mathrm{~cm}^{2}\right)$ stories appeared on the front page and $11\left(2206.05 \mathrm{~cm}^{2}\right)$ found to be placed on inside pages.

Sex trafficking and women's reproductive rights acquired the fourth position in order of importance in The Indian Express; the paper had covered 3 stories simultaneously in these two specific categories, wherein $702.5 \mathrm{~cm}^{2}$ space was given to sex trafficking and $457 \mathrm{~cm}^{2}$ space had attributed to women's reproductive rights by The Indian Express. The stories of sex trafficking got greater space than women's reproductive rights in the newspaper under study. While 
The Times of India had given the fourth position to the stories related to honour killing. The paper covered 3 $\left(424.25 \mathrm{~cm}^{2}\right)$ stories on this specific category, of which a single story with $16 \mathrm{~cm}^{2}$ appeared on the front page and rest of the 2 stories with the space of $408.25 \mathrm{~cm}^{2}$ got covered on its inside pages.

As regards dowry death and honour killing, The Indian Express placed it on the fifth place in order of importance: one story with $84.5 \mathrm{~cm}^{2}$ appeared on dowry death and one story with a space of $112 \mathrm{~cm}^{2}$ covered on honour killing by The Indian Express. Whereas The Times of India allotted the fifth slot in order of importance to child marriage, forced marriage, dowry death, and sex trafficking. On child marriage, forced marriage one story with $128.65 \mathrm{~cm}^{2}$ appeared exclusively on the front page of the newspaper. Likewise, a single story with a space of $98 \mathrm{~cm}^{2}$ covered in the category of dowry death by the paper and The Times of India also covered a single story with $25.65 \mathrm{~cm}^{2}$ of space on the front page on sex trafficking in this slot.

\section{CONCLUSION AND SUGGESTIONS}

The devastating consequences of male violence tend to jeopardisea woman, her family and society alike. The fatalistic physical and mental health is deeply associated with the social and economic costs. Women who have been victimized suffer both immediate and long-term consequences in terms of their physical and mental growth and stability.

Sexual violence has multiple organic, biological, behavioural, social, and economic consequences for women and their families. Thus, they suffer from pessimistic and defeatist upbringing. Sexual abuse, rape, and partner violence, also encompasses negative phenomenon related to bodily diseases such as high-risk sexual behaviour and sexually transmitted diseases. Actually, unwanted pregnancy is highly correlated with exposure to domestic violence including childhood physical and sexual abuse, rape, and partner violence committed by close relatives and familiar people in the family.

"Sexual violence takes multiple forms, which is rooted in patriarchal social structures and cultural roles of women and men and is reinforced by media images. The psychological, social, and behavioural effects of such violence on women, families, and society are widespread and long-lasting. Understanding, predicting, and preventing gender-based violence will require a complex and comprehensive approach that intervenes at individual, interpersonal, and structural levels and that is responsive to cultural difference” (Russo \& Pirlott, 2006).

Newspaper reports need to be revamped by creating correct social perceptions by write-ups which may pave way for a basic change in family and societal values. Proper enforcement of women's rights thus requires, educating people through newspaper articles, features, stories so that these rights are respected and observed in practice by the citizen of India. A soothing culture of women's rights has to be developed in our country.

National Human Right Commission and National Commission for Women has a greater role to play in dealing cases of women's rights violations and needs to recommend and take compensatory measures through advertisements in mainstream English dailies of the country. People also need to aware about the commission and it is now for the people to take help of these available institutions in order to inculcate women's rights values in the home, in the community, in the society, and in the public.

Also all the three pillars of the government i.e. legislature, executive, and judiciary must now respect and promote this culture of human rights specially for the women, the weaker section of the society, so that sexual violence in multiple forms like child abuse, honour killing, dowry death, trafficking in women and children, etc. can be tackled to a greater extent. Even the NGOs, welfare agencies, legal experts, civil society and social workers have to play an important role to secure the rights of the women through advocacy, providing legal aids and legal education in the grass-root level to the top. And, the press and media, especially mainstream English dailies and vernacular language newspapers, can play a vital role to raise and highlight the concerns of women's rights by publishing articles from legal experts, women's rights activists and experts of women's commission and so on.

\section{REFERENCES}

[1] Amnesty International. (2004). It's in our hands: Stop violence against women. Osney Mead, Oxford, UK: Alden Press.

[2] Berns, N. S. (2004). Framing the victim: Domestic violence, media and social problems, (Ist ed.). New York, NY: Routledge.

[3] CEDAW. (2008). Convention on the elimination of all forms of discrimination against women. UN women. Retrieved from http://www.un.org/womenwatch/daw/cedaw/ (accessed 1 March 2019).

[4] Heeron, J., \& Messing, J. (2009). Victims and sources: Newspaper reports of mass murders in domestic contexts. In D. Humphries (Ed.), Women, violence, and the media: Readings in feminist criminology. Boston: North eastern University Press.

[5] Khondaker, M. and Barlow, M. (2009). Rapist freed. Victim punished: Newspaper accounts of violence against women in Bangladesh. In D. Humphries (Ed.), Women, violence, and the media: Readings in feminist criminology. Boston: Northeastern University Press.

[6] Martin, K. A. (2013). Domestic violence, sexual assault, and sex trafficking in the media: A content analysis (Master's dissertation). Michigan, USA: Department of Sociology, Anthropology, and Criminology, Eastern Michigan University.

[7] Noh, M. S., Lee, M., \& Feltey, K. M. (2010). Mad, bad, or reasonable? Newspaper portrayals of the battered woman who kills. Gender Issues, 27, 110-130.

[8] RAINN. (2010). Retrieved from https:/www.rainn.org/statistics/ victims-sexual-violence (accessed 1 March 2019).

[9] Russo, N. F., \& Pirlot, A. (2006). Gender-based violence concepts, methods, and findings. New York Academy of Sciences, 1087, 178205. DOI: 10.1196/annals.1385.024. 